\title{
MODEL KOMUNIKASI INTERPERSONAL GENERASI MUDA SUKU BATAK KARO DI YOGYAKARTA MELALUI TRADISI ERTUTUR
}

\author{
Bastanta Bernardus Peranginangin dan Yudi Perbawaningsih
}

Program Studi Ilmu Komunikasi, FISIP, Universitas Atma Jaya Yogyakarta

Jl. Babarsari No. 6, Yogyakarta 55281, Telp (0274) 487631, Hp. 081578784411

email: bernardusperanginangin@gmail.com

\begin{abstract}
Karonese Batak tribe has ertutur tradition. It is communication of someone when meet people for the first time to get position in the custom and family relationship (pertuturen). When someone meets people for the first time, he or she reduces uncertainty by information seeking. This paper aims at analysing ertutur Karonese tradition as interpersonal communication model for Karonese young people living in Yogyakarta using uncertainty reduction theory. Using qualitative method, data were collected by in-depth interview and participatory observation to Karonese young people living in Yogyakarta. The research found that many young Karonese people living in Yogyakarta have difficulties in starting communication. Ertutur tradition can be one way to start communiation.
\end{abstract}

Key Words: Interpersonal Communication, uncertainty reduction theory, ertutur, Karo.

\begin{abstract}
Abstrak
Suku Batak Karo memiliki Tradisi ertutur yang merupakan komunikasi seseorang ketika pertama kali bertemu dengan orang lain untuk mendapatkan kedudukan dalam adat dan keterkaitan kekeluargaan (pertuturen). Ketika orang pertama kali bertemu, mengurangi ketidakpastian dengan mencari informasi (information seeking). Tujuan penelitian ini untuk menganalisis tradisi ertutur Karo sebagai model komunikasi interpersonal generasi muda perantau di Yogyakarta. Teori yang digunakan antara lain Uncertainy Reduction Theory. Metode penelitian secara kualitatif dengan pengumpulan data wawancara mendalam serta observasi partisipan di kalangan pemuda pemudi Karo yang merantau di Yogyakarta. Hasil penelitian ditemukan banyak generasi muda kesulitan dalam memulai komunikasi. Tradisi ertutur ini dapat menjadi cara dalam memulai komunikasi.
\end{abstract}

Kata Kunci : $\quad$ Komunikasi Interpersonal, Uncertainy Reduction Theory, ertutur, Karo

\section{Pendahuluan}

Dalam menjalin sebuah relasi, sikap saling memahami menjadi modal utama dalam membangun relasi tersebut. Hal ini dipengaruhi oleh bahasa, latar belakang (budaya) dan tujuan, hingga terbangun kontak sosial dalam relasi itu sendiri maupun dengan orang disekitar kita. Relasi yang terjalin tersebut bergantung pada cara setiap pihak dalam mengkomunikasikan diri (verbal maupun non verbal). Dalam relasi yang baik dengan saling memahami tersebut, harus terdapat kemampuan untuk berpikir maupun berperilaku seperti yang kita (saling) inginkan (Mulyana, 2010:4). Komunikasi tersebut terbentuk suatu interaksi dan secara bersama-sama sampai pada tujuan yang sama.

Setiap orang membangun relasi membutuh-kan kemampuan untuk berkomunikasi. Terlebih dalam relasi interpersonal, karena "keberhasilan komunikasi menjadi tanggung jawab para peserta komunikasi" (Mulyana, 2010:81). Selain itu pengakuan satu sama lain menjadi pondasi yang penting dalam membina relasi interpersonal 
tersebut. Relasi interpersonal tentu membutuhkan komunikasi interpersonal juga sehingga terwujud perkataan yang benar dan perbuatan yang baik dalam relasi tersebut. Terlebih sebagai bangsa Indonesia yang memiliki beragam suku, budaya, tradisi dan adat istiadat. Salah satu suku itu adalah suku Batak di Sumatera Utara. Suku batak memiliki sub-sub salah satunya adalah Suku Batak Karo. Suku Batak karo memiliki tradisi yang dilakukan oleh setiap orang Batak ketika pertama kali berjumpa dan bertemu. Menurut Edward WvanaPritchard (1986:154) dalam tulisan Yulius Limbong dalam bukunya berjudul "Orat Tutur Karo" tahun 1995 disebutkan :

Dalam tiap-tiap masyarakat (Batak Karo), walaupun dalam bentuk yang paling sederhana sekali, kita akan dapat menemui suatu bentuk kehidupan keluarga, pengakuan mengenai ikatan kekeluargaan, sistem ekonomi dan politik, status sosial, ibadah agama, cara menyelesaikan konflik dan hukuman terhadap penjahat dan lain-lain disampingkan kebudayaan terhadap material, suatu kumpulan pengetahuan mengenai alam semesta, taknik dan tradisi (Limbong, 1995: 3)

Guna mengetahui kekeluargaan tersebut suku Batak memiliki tradisi untuk memulai pembicaraan. Suku Batak Karo menyebut tradisi tersebut ertutur. Tradisi ertutur adalah suatu keharusan atau suatu proses untuk menentukan pertuturan (hubungan) berdasarkan margalima(5) macam(mergasilima), tutur delapan (tutur siwaluh) dan ikatan tiga (3) macam (rakut sitelu) (Barus, 1995:30). Suku Batak Karo yang menganut sistem Patrilineal untuk merujuk pada penentu garis keturunan yang disebut Marga (Ulih, 1995:5). Dewasa ini kecenderungan generasi muda untuk memahami esensi dasar dari tradisi ertutur mulai terkikis.
Generasi muda suku Batak kurang memahami kaidah tradisi yang didasari oleh merga silima, tutur siwaluh dan rakut sitelu ( Hutagaol, 2013: 3). Hal ini berakibat pada perilaku generasi muda Batak Karo dalam menempatkan diri terhadap sesama orang Batak maupun terhadap orang yang lebih tua.

Ketika orang Batak Karo pertama kali bertemu tradisi ertutur ini menjadi awal mula berlangsungnya pembicaraan atau komunikasi. Pembicara saling bertukar informasi. Informasi yang ada menjadi landasan dalam menciptakan tujuan yang sama berupa kesepakatan dari tutur mereka. Komunikasi dalam ertutur ini mencakup komunikasi interpersonal. Komunikasi interpersonal yang berjalan dengan aktif ketika proses komunikasi yang berlangsung membantu seseorang untuk merasa lebih baik secara fisik dan psikologis (West dan Turner, 2009:24). Pada semua proses komunikasi tersebut akan ada suatu keterkaitan hubungan pada kedua belah pihak yang ingin berkomunikasi. Penelitian ini akan mencoba menjelaskan cara orang Batak mengawali komunikasi dengan Ertutur. Mencari informasi (information seeking) dengan ertutur sehingga sampai pada kesepakatan dan diharapkan dapat mengurangi ketidaknyamanan dan penilaian subyektif pihak yang berkomunikasi (West dan Turner, 2009:175).

Dari sebab itu dapat peneliti rumuskan permasalahan adalah bagaimana tradisi ertutur suku Batak Karo sebagai model komunikasi interpersonal generasi muda perantau di Yogyakarta? Peneliti berharap bahwa skripsi ini dapat menjawab permasalahan yang ada sehingga dapat memahami tradisi ertutur suku Batak Karo sebagai model komunikasi interpersonal generasi muda perantau di Yogyakarta. 


\section{Kerangka Teori}

Deddy Mulyana mendefinisikan bahwa komunikasi interpersonal sebagai komunikasi antara orang-orang secara tatap muka, yang memungkinkan setiap pesertanya menangkap setiap reaksi secara langsung baik verbal maupun non verbal. Selain itu kualitas atau intimitas komunikasi interpersonal atau antarpribadi ini ditentukan oleh peserta komunikasi (Mulyana, 2010:81). Proses komunikasi ini berjalan sesuai dengan situasi dan kondisi dari peserta. Dalam komunikasi interpersonal ini melibatkan dua orang dalam jarak yang dekat (dyadic communication). Komunikasi Interpersonalsangateratkaitannyadengan relasi yang terjalin antara komunikan dan komunikator. Komunikasi mereka saling terlibat dalam suatu hubungan yang saling menguntungkan dan saling ketergantungan serta menimbulkan kepuasan hati pada kedua belah pihak (Suranto, 2011:27). Komunikasi interpersonal ini menjadi penting misalnya dalam pertemuan pertama kali karena bersifat dialogis (Kurniawati, 2014:6).

Komunikasi antarpribadi terjadi pertukaran informasi dalam tradisi ertutur Suku Batak Karo. Kedua belah pihak dapat mengajukan pertanyaan sementara lainnya memberikan jawaban. Komunikasi tersebut meyakinkan kita tentang relasi, diantaranya entah kenalan lama, kekasih atau anggota keluarga. Komunikasi antarpribadi ini juga berfungsi untuk membina, memelihara, kadang-kadang merusak dan kadang kala memperbaiki hubungan antarpribadi tersebut. Komunikasi interpersonal erat kaitanya dengan latar belakang individu. Pengetahuan, persepsi, pengetahuan, budaya akan memberikan pengaruh kepada kondisi atau kualitas komunikasi dalam individu bersangkutan. Selanjutnya, peneliti menjabarkan keterkaitan komunikasi interpersonal yang terkait dengan model komunikasi dalam proses komunikasi.

Deddy Mulyana menuliskan salah satu model komunikasi dicetuskan Wilbur Schramm yakni menggunakan serangkaian model komunikasi dari yang sederhana sampai yang lebih rumit yang memperhitungkan pengalaman dua individu. Model Scramm mengemukakan tiga model, pertama model yang mirip dengan yang dicetuskan olehShannon dan Weaver yakni sumber yang menyanikan (kata dasar: Sandi) atau menciptakan pesan dan menyampaikannya melalui satu saluran kepada seorang penerima yang menyandi-balik atau menciptaulang pesan tersebut (Mulyana, 2010:149). Kedua Scramm memperkenalkan gagasan yang berdasar pada pengalaman antara sumber dan sasaran yang sama untuk dikomunikasikan. Ketiga interaksi dengan kedua belah pihak saling menyandi, menafsirkan dan sebaliknya (Mulyana, 2010: 151). Ketiga model komunikasi tersebut dapat dilihat pada bagan 1 .

Ketiga model komunikasi yang dikemukakan Schramm memberikan gambaran bagaimana unsur-unsur yang terjalin dalam komunikasi. Model Schramm erat terkait pada komunikasi verbal maupun non verbal, di mana terdapat tiga unsur dalam model ini yakni individu maupun organisasi sebagai sumber (source), tinta pada kertas atau suara pada gelombang radio sebagai pesan (message) dan sasaran (destination) yang merupakan suatu individu atau anggota suatu kelompok (Mulyana, 2010: 151-153).

Model Schramm ini dipilih karena ketiga unsur yang disebutkan yakni source, message, dan destination akan menjadi sangat penting dalam penelitian ini. Selain decoder dan encoder sebagai penyandi dan penyandi-balik dari 


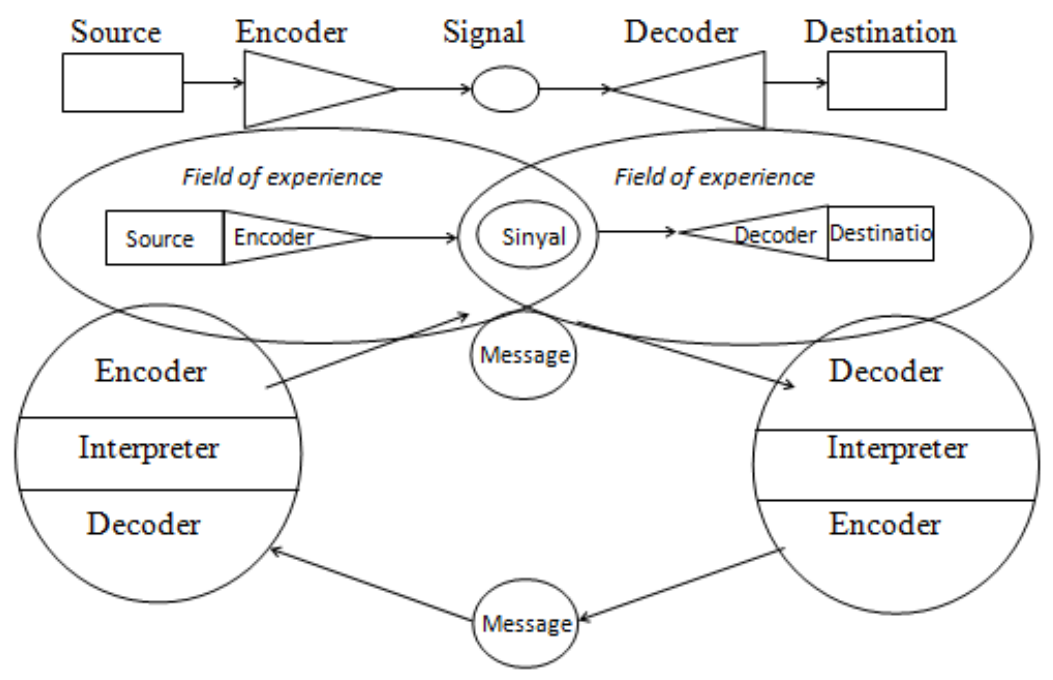

Bagan 1. Model Schramm (Sumber:Deddy Mulyana, 2010:152).

pesan yang ada, field of experience juga menjadi hal yang penting. Field of experience akan ditempatkan sebagai pemahaman individu mengenai tradisi ertutur. Model Schramm juga sedemikian mengharapkan pentingnya umpan balik (feedback) dari proses komunikasi yang berlangsung.

Teori Pengurangan Ketidakpastian (Uncertainly Reductions Theory) merupakan salah satu dari teori komunikasi interpersonal. Ketika dua orang yang pertama kali berjumpa maka sedikit sulit untuk memulai pembicaran. Hal ini menimbulkan banyak ketidaknyamanan atau penilaian subyektif yang kemudian akan menimbulkan pertanyaan-pertanyaan (West dan Turner, 2009:135). Pertanyaan tersebut akan muncul dugaan- dugaan positif maupun negatif, sehingga akan muncul berbagai ketidakpastian.

Teori pengurangan ketidakpastian (Uncertainty Reduction Theory) dicetuskan olehCharles Bergerdan Richard Calabrese. Implementasi teori ini dalam komunikasi dipergunakan sebagai pengurangan ketidakpastian sebagai tujuan dari teori ini. Ketidakpastian ini memiliki dua (2) jenis yakni ketidakpastian kognitif, yakni: (1) Ketidakpastian yang berhubungan dengan keyakinan atau sikap. Keyakinan ini bisa dibuat oleh diri sendiri atau orang lain. (2) Ketidakpastian perilaku yakni ketidakpastian yang memiliki batasan perilaku-perilaku yang dapat diprediksi. Teori pengurangan ketidakpastian ini juga disebut sebagai teori aksiomatik, sehingga teori ini merupakan teori lanjutan yang dikembangkan oleh Berger dan Calabrese.

Teori pengurangan ketidakpastian memiliki tujuh aksioma yakni: (1) Adanya tingkat ketidakpastian yang tinggi pada permulaan fase awal ketika jumlah komunikasi verbal antara dua orang asing meningkatkan, tingkat ketidakpastian untuk tiap partisipasi dalam suatu hubungan akan menurun. Jika ketidakpastian menurun, jumlah komunikasi verbal meningkat. Hal ini menyatakan adanya kebalikan atau hubungan negatif antara ketidakpastian dan komunikasi verbal. (2) Ketika ekspresi afiliatif non verbal meningkat, tingkat ketidakpastian menurun dalam situasi interaksi awal. Selain itu, penurunan tingkat ketidakpastian menyebabkan peningkatan ekspresifan afiliatif non verbal. Hal ini merupakan salah satu hubungan yang bersifat negatif. (3) Tingkat ketidakpastian yang 
tinggi menyebabkan meningkatnya perilaku pencarian informasi. Ketika tingkat ketidakpastian menurun maka perilaku pencarian informasi menurun. Hal ini berkaitan dengan sikap positif antara kedua konsep tersebut. (4) Tingkat ketidakpastian yang tinggi dalam sebuah hubungan menyebabkan penurunan tingkat keintiman isi komunikasi. Tingkat ketidakpastianyangrendahmenghasilkan tingkat keintiman yang tinggi. Aksioma ini memperlihatkan hubungan yang negatif antara ketidakpastian dan tingkat keintiman. (5) Ketidakpastian yang tingkat tinggi menghasilkan resiprositas (menyatakan jika seseorang memberikan detail personal, lainnya akan melakukan hal yang sama) yang tinggi. Tingkat ketidakpastian yang rendah menghasilkan tingkat resiprositas yang rendah pula. Hubungan positif terjadi di sini. (6) Kemiripan antara orang akan mengurangi ketidakpastian, sementaara ketidakmiripan akan meningkatkan ketidakpastian. Aksioma ini menyatakan hubungn negatif. (7) Peningkatan ketidakpastian akan menghasilkan penurunan dalam kesukaan; penurunan dalam ketidakpastian menghasilkan peningkatan dalam kesukaan. Ketujuh aksioma ini merupakan hal yang penting dalam teori pengurangan ketidakpastian (West dan Turner, 2009: 179-181).

\section{Ketidakpastian perjumpaan awal dibandingkan ketidakpastian} hubungan mapan, bergantung pada proses komunikasi yang terus menerus berlangsung dalam suatu hubungan hingga sampai pada proses pengurangan ketidakpastian (West dan Turner, 2009, hal. 185). Hal ini mungkin berfungsi secara dialektis dalam hubungan dan dapat saja terjadi ketengangan. Konteks ini perlu juga kita ketahui perilaku orang lain yang menyebabkan kebosanan (West dan Turner, 2009:185). Pada penelitian ini, peneliti akan berfokus pada hubungan yang baru pertama kali berjumpa. Peneliti ingin mengetahui proses komunikasi berlangsung secara dialektis dan unsur apa yang paling utama yang bisa memberikan pengurangan ketidakpastian dalam proses komunikasinya secara interpersonal.

$\begin{array}{lll}\text { Konsep yang } & \text { mirip dengan } \\ \text { teori } & \text { pengurangan } & \text { ketidakpastian } \\ \text { adalah } & \text { penghindaran } & \text { ketidakpastian }\end{array}$ (uncertainty avoidance). Penghindaran ketidakpastian merupakan untuk menolak atau menghindari situasi yang ambigu (West dan Turner, 2009:188). Peneliti melihat bahwa penghindaran ketidakpastian bukanlah jawaban dari penentuan atau kesepakatan dalam menentukan tali kekerabatan diantara orang Batak.

Satu hal yang penting juga dalam teori ini adalah pembukaan diri (selfdisclosure), membuka informasi mengenai diri sendiri kepada orang lain untuk mencapai tujuan. Informasi yang dibagikan umumnya informasi yang signifikan. Tentu pada kajian ini tentu selain dalam proses komunikasi yang dibutuhkan feedback dan keterbukaan sangat diharapkan untuk mencapai tujuan (destination) yakni kesepakatan untuk menentukan kekerabatan dari tradisi ertutur tersebut.

\section{Metode Penelitian}

Jenis penelitian yang digunakan dalam penelitian ini adalah jenis penelitian kualitatif. Penelitian kualitatif adalah penelitian yang bermaksud untuk memahami fenomena tentang apa yang dialami oleh subjek penelitian misalnya perilaku, persepsi, motivasi, tindakan dan lain-lain, secara holistik, dan dengan cara deskriptif dalam bentuk kata-kata dan bahasa, pada suatu konteks khusus yang alamiah dan dengan memanfaatkan berbagai metode alamiah (Moleong, 2007:6). 
Metode penelitian yang dilakukan adalah penelitian dengan etnografi. Penekanan etnografi lebih diarahkan kepada element sentral yang mengacu pada observasi partisipan, dimana diharapkan peneliti lebih dekat dengan mereka (informan). Peneliti mengamati dinamika pola komunikasi dan tradisi ertutur itu diterapkan berkaitan dengan sandi dan penyandian balik (feedback) dan juga penanan dari Field of experience dalam perkenalan identitas diri. Wawancara etnograsi menjadi salah satu sarana untuk menelaah dinamika sosial yang terjadi.

Teknik dalam pengumpulan data dilakukan dengan dua cara yang pertama adalah dengan observasi. Metode observasi ini peneliti melakukan pengamatan langsung terhadap subyek diteliti. Metode observasi ini dapat dibagi menjadi dua (2) yakni Metode Observasi Partisipan yakni peneliti terjun langsung dalam penelitian itu dan Nonpartisipan yakni peneliti memposisikan diri tidak sebagai anggota yang diteliti, selain itu ada pula observasi partisipanmembership yakni peneliti adalah anggota dari kelompok yang diteliti.

Kedua adalah metode wawancara mendalam (Depth Interview). Metode depth interview merupakan dapat dilakukan dengan tatap muka secara mendalam dan terus-menerus (lebih dari satu kali) untuk menggali informasi dari responden (Kriyantono, 2008: 63).

Analisis data kualitatif (Bogdan dan Biklen,1982) adalah upaya yang dilakukan dengan jalan bekerja dengan data, mengkategorisasikan data, dan memilah-milah menjadi satuan yang dapat dikelola, mensintesiskannya, mencari dan menemukan pola, menemukan apa yang penting dan apa yang dipelajari dan memutuskan apa yang dapat diceritakan kepada orang lain (dalam Moleong, 2013:248). Pada bagian analisis ini, peneliti mulai dengan mengumpulkan data dari hasil observasi lapangan data baik tertulis maupun lisan mengenai pemahaman dan cara orang Batak jika bertemu dengan orang batak lainya hingga masuk pada dinamika tradisi ertutur yang diterapkan ketika pertama kali bertemu. Cara generasi muda Batak Karo untuk memulai pembicaraan di perantauan mengenai tradisi ertutur tersebut. Hal tersebut mengenai perilaku orang Karo dalam pertama kali berjumpa dengan sesama Batak. Cara mereka berkomunikasi, menempatkan diri, dan prilaku dalam perjumpaan tersebut. Tradisi ertutur tersebut dilakukan pada saat pertama kali bertemu atau sudah lama bertemu. Tentu hal ini untuk mencari informasi (information Seeking).

Informan penelitian adalah orang atau pihak yang dimanfaatkan untuk memberikan informasi tentang sitausi dan kondisi latar belakang penelitian (Moleong, 2000: 97). Penelitian ini sesuai dengan judul maka yang menjadi narasumber atau informan penelitian ialah generasi muda. Generasi muda yang dimaksud adalah mahasiswa/i suku Karo yang berdomisili di Kota Yogyakarta yang berasal dari luar kota Yogyakarta atau yang merantau di Yogyakarta.

\section{Hasil Penelitian dan Pembahasan}

Melalui tradisi ertutur Suku Batak Karo ini dapat menjadikan salah satu cara untuk memulai komunikasi dalam menemukan garis kekeluargaan di antara mereka. Pada umumnya tradisi ini dilakukan ketika pertama kali berjumpa dengan seseorang. Terlebih jika mengacu pada pemahaman generasi muda mengenai tradisi ertutur ini yang menunjukan bahwa setiap orang Suku Batak Karo di Dunia adalah keluarga.

Pemahaman bahwa semua orang Karo adalah keluarga dapat ditinjau dari proses ertutur dengan menanyakan 
Marga, Beru, Soler, Kampah, maupun Binuang, menjadi modal awal secara tidak langsung bahwa sesama orang Batak mudah untuk bergaul dalam konteks ini memulai pembicaraan. Tentu hal ini tidak semudah untuk menanyakan apa lagi ketika bertemu dengan orang pertama kali. Komunikasi yang baik dan mencari informasi mengenai "kebatakan" seseorang yang dijumpai menjadi salah satu hal yang penting untuk dapat memulai pembicaraan, hingga untuk mengetahui alur kekerabatan yang ada sehingga ertutur dapat berjalan dengan baik diantara dua individu.

Suku Batak Karo memiliki ciri khas dalam menyampaikan salam perjumpaan yakni dengan mengucapkan "Mejuahjuah" sambil berjabat tangan atau dengan mengangkat tangan sebagai tanda sapaan. Salam ini sebagai tanda pembuka pembicaraan atau dapat disebutkan sebagai komunikasi non verbal dalam ranah komunikasi interpersonal. Selain salam tersebut kebiasaan orang suku Batak dalam konteks ini suku Batak Karo menunjukkan suatu pemahaman mengenai sebutan (pertuturen). Bagi orang Karo Salam “Mejuah-juah!” dan sebutan (pertuturen) kerap menjadi titik awal ketika ingin berkenalan dengan orang yang baru pertama kali bertemu, dan memastikan cara untuk memulai ertutur. "Mejuah-juah! Pal" diucapkan kepada pria mau pun wanita Karo. "Mejuah-juah! Senina" diucapkan kepada sesama jenis kelamin Karo saja. "Mejuahjuah!, Turang" diucapkan kepada lawan jenis kelamin Karo saja. Ucapan ini dibarengi dengan saling berjabat tangan dan ekspresi wajah. Ucapan verbal ini memulai komunikasi dalam suatu pertemuan.

Komunikasi non verbal dengan bersalaman dibalas juga dengan bersalaman menjadi tanda komunikasi non verbal yang saling dipertukarkan (feedback). Paham atau tidak mengenai ertutur akan terabaikan ketika jabatan tangan dalam salam tersebut disambut menjadi tanda atau sinyal penting dalam meneruskan komunikasi mengenai ertutur. Perilaku saling bersalaman ini menjadi sumber (source) bagi kedua belah pihak untuk memulai saling bertukar informasi (message). Dan kemudian disambut salam dan jabat tangan (receiver) atau umpan balik sehingga efek dari tindakan tersebut adalah komunikasi yang berjalan mengenai ertutur tersebut untuk menanyakan marga atu beru serta hal-hal yang terkait hingga sampai pada kesepakatan ertutur yang diinginkan. Sementara hambatan yang terjadi dalam tradisi tersebut adalah ketika berhadapan dengan orang yang minim pengetahuan mengenai ertutur tersebut.

Komunikasi dalam ertutur hanya dapat dilakukan dengan baik dan efektif jika sama-sama saling memiliki pengalaman maupun pemahaman yang sama mengenai komunikasi dalam konteks ini pengalaman mengenai ertutur. Komunikasi akan mengalami hambatan ketika harus berhadapan dengan ketidaksamaan pemahaman atau pengalaman mengenai komunikasi tersebut. Jabat tangan tidak disambut dan kata "Mejuah-juah!" tidak digubris maka dalam memulai komunkasi untuk ertutur tidak dapat dilanjutkan atau berhenti. Kesamaan akan pengalaman mengenai ertutur diharapkan dapat memberikan kemudahan dalam berkomunikasi sampai pada pembentukan kesepakatan. Uluran tangan untuk berjabatan diterima dan salam "Mejuah-juah" pun disambut dengan "Mejuah-juah!" maka kemungkinan komunikasi dapat dilanjutkan .

Melalui tradisi ertutur ini juga selain untuk posisi dalam upacara adat, juga mempengaruhi cara berbicara atau berperilaku kepada yang lain. Terlepas 
dari jenjang umur yang ada akan memberi pengaruh. Sebab bagi orang Batak Karo cara menyapa seseorang itu ditentukan dari orat tutur yakni merga silima, tutur siwaluh dan rakut sitelu. Karena ertutur mempengaruhi cara kita berperilaku dan bertutur sapa.

Pertanyaan mengenai asal dan tempat tinggal tentu menjadi salah satu alternatif yang lebih mudah dalam menentukan kesepakatan dalam ertutur tersebut. Menanyakan kampung atau daerah asal dilakukan untuk mengetahui kekerabatan yang paling dekat. Apa lagi jika di kampung tersebut kedua belah pihak memiliki kenalan atau orang yang sama dan telah diketahui tutur salah satu pihak denganya. Tentu kesepakatan dalam ertutur mudah untuk disepakati kendati dapat berubah sewaktu-waktu.

Penghormatan kepada orang tua juga diterapkan oleh anak muda, bahwa setiap ide dan pemikiran mereka ikut sertakan pada saat eksekusi ide tersebut. Sdr. Plato Ginting, sebagai seorang anak muda Suku Karo perantau di Yogyakarta dipercayakan sebagai penasehat dalam acara tersebut. Beliau berpendapat bahwa acara Gendang yang dilaksanakan kali kedua, sejak 2014 dengan tema Gendang Sada Wari dan tahun 2015 Gendang Dalinta Jumpa Mulihi, dapat menjadi sarana menumbuh kembangkan kecintaan anak muda dalam memahami identitas budaya Karo. Karena itu partisipasi anak muda juga sangat diperhatian dalam hal tersebut.

Tetapi tidak jarang pula jika komunikasi mengenai ertutur ini tidak panjang lebar dilakukan. Ucapan “Mejuah-juah, Pal/ Senina/ Turang) menghiasi pembicaraan. Namun demikian pembicaraan mengenai ertutur tersebut terhentisampaipada tahapitu saja dan kerap ditutup dengan menanyakan nomor HP, Pin BBM atau alamat sosial media lainnya. Tidak dapat dipahami apa dan bagaimana cara generasi muda ini melanjutkan komunikasinya via media. Kendati tujuan sama kerap intensitas komunikasi dengan ertutur terabaikan.

Komunikasi merupakan suatu kemampuan seseorang untuk memahami satu sama lain sehingga tercipta suatu tujuan yang sama (West dan Turner, 2009:3). Selain itu fungsi dari komunikasi itu adalah konsep sosial, yang dimaksud dengan konsep sosial berkaitan dengan membangun konsep dan aktualisasi diri. Sehingga tujuan dari komunikasi tersebut yakni kebahagiaan dan terhindar dari ketegangan (Mulyana, 2010:6). Pemahaman komunikasi tersebut jika kita telaah dari teropong pamahaman generasi muda mengenai ertutur cukup beragam. Benar dalam ertutur bahwa kita dapat mememunculkan konsep diri ditengah kehidupan sosial dan merupakan aktualisasi diri dalam hidup sangkep ngeluh.

Tradisi Ertutur bukan hanya melulu membahas mengenai inti pembicaraan dalam berkomunikasi tetapi berkaitan dengan lingkup bagaimana seseorang mampu untuk memulai komunikasi. Mulai dari seeking information secara non verbal, kemudian bisa memulai komunikasi secara verbal dengan tahap tersebut sampai pada kesamaan konsep dan tujuan dalam komunikasi ertutur tersebut. Komunikasi yang baik terjadi jika pesan yang disampaikan tepat tujuan. Tentu dalam memulai komunikasi kita harus mampu untuk mengurangi ketidakpastian yang timbul dalam pemikiran manusia terhadap orang yang ingin kita ajak berkomunikasi.

Orang Batak Karo dalam kehidupan sehari-hari tidak akan sulit untuk memulai komunikasi jika mengetahui pasti bahwa sama-sama orang Karo atau orang Batak pada umumnya. Untuk mencari tahu hal tersebut pada URT ada tiga strategi yang dapat dilakukan 
untuk mengurangi ketidakpastian tersebut. Ketiga strategi tersebut adalah strategi pasif, strategi aktif dan strategi interaktif. Dalam tradisi ertutur strategi pasif, salah satu pihak (pasti orang Karo) akan mencoba mengamati dengan mencari tahu seseorang yang akan diajak berbicara. Pengamatan tersebut tanpa menganggu misalnya dengan melihat bentuk wajah, mendengar suara dan mencoba mencari tahu nama lengkap, orang Batak pada umumnya memiliki marga/beru (non verbal). Kemudian strategi aktif masuk ketika adanya kontak yang terjadi yakni mengucapkan "Mejuah-juah! Pal" (verbal) sambil mengulurkan tangan untuk bersalaman. Strategi ketiga adalah strategi interaksi dimana pada strategi ini terlibat dalam interaksi atau percakapan tatap muka. Tentu dibutuhkan pembukaan diri, mempertanyakan secara langsung dan adanya taktik pencarian informasi yang berlangsung.

Ketiga strategi tersebut sesuai dengan teori URT yang dicetuskan dalam komunikasi interpersonal. Pada proses komunikasi interpersonal identik dengan komunikasi verbal dan nonverbal serta. Merujuk pada komunikasi interpersonal melalui perspektif mengurangi ketidakpastian dari asumsi maupun aksioma teori tersebut. Ketidakpastian akan meningkat ketika bertemu dengan orang asing, wajar saja timbul banyak persepsi atau pikiran-pikiran negatif maupun positif mengenai orang asing tersebut. Walau begitu salah satu pihak dapat melihat atau mempelajari tingkah laku cara non verbal yang terekspesikan oleh pihak yang ingin diajak berkomunikasi. Pada tabel 2 tersebut tampak bahwa komunikasi non verbal akan aktif pertama kali untuk mencoba mengurangi ketidakpastian. Tingkat saling mengekspresikan diri dengan cara non verbal yang intim, akan terjadi kepastian yang lebih, karena kedua belah pihak saling menggunakan ekspresi wajah, kontak mata, bahkan saling bersentuhan sehingga keduanya merasa nyaman.

Komunikasi non verbal dalam tradisi ertutur ini tampak dari ketika kedua belah pihak saling bertemu, ciriciri fisik seperti bentuk wajah dan suara yang lebih mendominasi. Namun pun begitu komunikasi non verbal tersebut tidaklah dapat dipastikan serta merta. Karena akan mengacu pada pemahaman seseorang terhadap orang lain. Tindakan selanjutnya yang dilakukan adalah mengurangi ketidakpastian dengan memilih cara komunikasi lain yang akan dilakukan (Proaktif). Mencari informasi terlebih dahulu untuk memulai komunikasi. Misalnya dengan mencari tahu nama lengkap yang akan ingin diajak berkomunikasi. Mencari tahu nama marga/beru untuk nantinya jadi loncatan untuk berkomunikasi secara verbal (strategi pasif).

Setelah sedikit mengetahui identitasnya maka tentu kita mencari momentuntukmemulaikomunikasisecara interpersonal (verbal). Ini merupakan tahap awal dalam memulai pembicaraan yakni interaksi. Pada umumnya orang Karo dengan mengucapkan "Mejuahjuah, Pal!" sambil mengulurkan tangan untuk bersalaman dan mungkin bertanya nama "kai mergandu?". Pada tingkat ini, umumnya ketidakpastian masih tinggi sebagai fase awal dalam komunikasi verbal. Selanjutnya ketidakpastian akan menurun tergantung dari seberapa banyak kedua belah pihak untuk saling berbicara mengenai diri mereka satu sama lain.

Keterbukaan diri (self-disclosure) dapat dilihat dari cara individu untuk menunjukkan identitas personal. Sebab tradisi ertutur bertujuan untuk mendapat kesepakatan dalam menentukah garis 
kekeluargaan atau kekerabatan. Dalam mengarahakan pembicaran ertutur ini, untuk sampai pada kesepakatan tentu berdasar pada karakter, latar belakang, pendidikan dan pengalaman (Pemahaman Orat Tutur) pihak yang terlibat dalam berkomunikasi. Pengalaman atau pemahaman yang sama mengenai ertutur menjadi kunci dalam menentukan kualitas komunikasi. Sinyal yang disampaikan dapat berupa marga yang tersemat dibelakang nama pokok, tentu pemahaman itu akan mempermudah dalam memulai komunikasi.

Secara garis besar bahwa generasi muda perantau di Yogyakarta melihat bahwa tradisi ertutur suku Batak Karo ini penting untuk diimplementasikan. Mencari informasi yang bisa didapatkan sebelum memulai interaksi akan mempermudah pihak yang berkomunikasi untuk saling mengenal satu sama lain. Adanya sikap segan (sihangken) bagi orang Batak Karo menunjukkan bahwa ertutur menjadi sarana yang penting dalam memulai interaksi hingga menemukan hubungan kekerabatan. Tradisi ertutur bagi generasi muda menjadi model komunikasi yang dapat diimplementasikan dalam kehidupan sehari-hari.

\section{Simpulan}

Komunikasi ertutur terkait dengan pengurangan ketidakpastian benar bahwa dibutuhkan keterbukaan diri (self disclosure). Keterbukaan diri hanya dapat tercapai dengan adanya feedback. Namun yang kerap terjadi perkembangan teknologi kerap menggerus cara berkomunikasi dalam tradisi tersebut. Hal ini tampak dari peranan gadget atau HP, sosial media dan semua sarana komunikasi yang sulit untuk dibendung. Hal ini tentu menjadi ancaman eksistensi tradisi ertutur tersebut.
Sifat komunikasi interpersonal dyadic (jarak yang dekat dan bertatap muka), bagi generasi muda perantau di Yogyakarta tergerus karena eksistensi HP dan media sosial lainya. Tidak jarang jika komunikasi interpersonal tersebut menjadi terabaikan, atau lebih tepatnya tidak berjalan dengan semestinya. Memang benar jika melalui media komunikasi masih terjadi antara kedua belah pihak dan dewasa ini banyak hubungan berjalan dengan baik melalui media sosial juga. Tetapi sebagai peneliti berpendapat bahwa ertutur bukan sekedar komunikasi tetapi juga bagiamana kedua individu mampu untuk menciptakan rasa lebih dari sekedar berkenalan tetapi sampai pada keutuhan kekeluargan (sedarah).

Berdasarkan penelitian ini, disimpulkan bahwa tradisi ertutur setelah peneliti analisis dengan teori pengurangan ketidakpastian maka tampak bahwa unsur-unsur yang terkait dengan komunikasi interpersonal tercakup di dalam tradisi tersebut. Kesepakatan menjadi inti utama sebagai tujuan komunikasi dalam ertutur. Kesepakatan tersebut yakni kesepakatan untuk memulai relasi interpersonal atau tidak. Efek atau hasil proses ertutur untuk melanjutkan keintiman dalam berelasi atau berkomunikasi. Dari sebab itu Feedback menjadi hal terpenting untuk ertutur, sebab tanpa adanya feedback proses ertutur itu tidak akan dapat sampai pada pemahaman yang semestinya. Tentu keterbukaan (self disclosure) menjadi hal yang tidak mungkin tidak harus ada dan melekat pada pihak-pihak yang terlibat dalam ertutur tersebut. Komunikasi yang baik dan benar menjadi kunci bagi setiap orang dalam mengungkapkan dirinya. Tanpa ada komunikasi yang baik dan benar maka seseorang akan tersesat dalam hidup sosial sebab mausia ada mahkluk yang berbicara (homo loquens). 
Dalam perjumpaan pertama kali kendati pun memiliki tujuan yang sama untuk hadir tetapi tidak untuk bertemu, tentu sikap ketidakpastian akan selalu tinggi. Demikian juga halnya dalam tradisi ertutur tersebut pemahaman akan suatu hal yang mengarah pada meningkatkan prediktabilitas (kepastian) pada pertemuan awal dengan berkomunikasi yang bersifat dialogis, komunikasi dapat berjalan dengan baik dan ketidakpastian dapat menurun. Komunikasi interpersonal sebenarnya menjadi sarana yang tepat dalam mengurangi ketidakpastian yang ada, sehingga tercipta mutual understanding.

Implementasi dari penelitian ini bahwa generasi muda suku Batak harus mampu lebih untuk memulai komunikasi secara aktif dan melihat tradisi ertutur sebagai suatu kekayaan. Setiap individu, baik berasal dari Tanah Karo atau bukan, sikap saling memahami dan memaklumi menjadi hal yang penting dalam berkomunikasi dan menjalin relasi. Penelitian ini masih dapat dilanjutkan untuk mendapatkan relasi yang lebih intim bagi orang Batak Karo. Tradisi ertutur merupakan suatu keunikan yang patut untuk ditelaah lebih dalam dan lebih spesifik lagi.

\section{Daftar Pustaka}

Aw, Suranto. 2011. Komunikasi Interpersonal. Yogyakarta :Graha Ilmu.

Bangun, Payung. (ed). 1988. Kebudayaan Batak dalam Koentjaraningrat, Manusia dan Kebudayaan di Indonesia. Jakarta, Indonesia: Djambatan.

Barus, U.C. dan Mberguh Sembirng. 1995. Sejemput Adat Budaya Karo (Sekilas Adat Budaya Karo. Medan.

Beebe, Steven A., Susan J. Beebe., and Diana K. IVY. 2010. Communicarion Principles for a Lifetime. Fourth
Edition, Boston, New York: Pearson Education, Inc. Allyn \& Bacon.

Bungin, Burhan. 2007. Analisa Data Kualitatif : Pemahaman Filosofis dan Metodologis ke Arah Penguasaan Aplikasi. Jakarta, Indonesia: Rajawali Press.

Cutlip, S. M., Center, A. H., \& Broom, G. M. 2009. Effective public relations. Jakarta, Indonesia: Kencana Pernada Media Group.

Devito, Joseph, A. 1997. Human Communication. New York: Harper Collinc Colege Publisher.

Gintings, E.P. 1995. Adat Istiadat Karo: Kinata Berita Si Meriah Ibas Masyarakat Karo. Kaban Jahe, Indonesia: Percetakan GBKP Abdi Karya.

Gintings, Perdana. 1989. Masyarakat karo dewasa ini. hasil rumusan Sarasehan Budaya karo 1989.

Effendi, Onong Uchjana. 2006. Teori Dan Praktik Ilmu Komunikasi. Bandung: Resdakaya.

Hakim, M. N. 2003. Islam Tradisional dan Reformasi Pragmatisme. Malang: Bayu Media Publishing.

H. P., Rosmawati. 2010. Mengenal Ilmu Komunikasi. Bandung: Penerbit Widya Padjadjaran.

Kozok, Uli. 1999. Surat Batak. Pengantar Filologi dan Aksara Batak. Medan: University of North Sumatra Press.

Kriyantono, Rachmat. 2006. Teknik PraktisRiset Komunikasi Disertai Contoh Praktis Riset Media, Public Relations, Advertising, Komunikasi Organisasi, Komunikasi Pemasaran. Jakarta: Kencana Prenada Media Group.

Kurniawati, Rd. Nia Kania. Komunikasi Antar Pribadi; Konsep dan Teori Dasar. Yogyakarta: Graha Ilmu. 
Mahjunir. 1967. Mengenal Pokok-Pokok Antropologi dan Kebudayaan. Jakarta: Bhratara.

Moehadjir, Noeng. 1998. Metodologi Penelitian Kualitatif. Yogyakarta : Rake Sarasin.

Moleong, Lexy J. 2013. Metodologi Penelitian Kualitatif. Bandung, Indonesia: PT. Remaja Rosdakarya.

Mulyana, D. 2010. Ilmu Komunikasi Suatu Pengantar. Bandung, Indonesia: PT. Remaja Rosdakarya.

Neumann, J. H. 1972. Sejarah Batak Karo: Sebuah Sumbangan. Jakarta, Indonesia: Bhratara.

Prinst, Darwin. 2004. Adat Karo. Medan, Indonesia: Bina Media Printis.

Siahaan. N. 1964. Sejarah Kebudayaan Batak. Medan: CV. Napitupulu \& Sons.

Sihabudin, Dr. H. Ahmad. 2011. Komunikasi Antarbudaya: Suatu Prspektif Multidimensional. Jakarta: PT. Bumi Aksara.

Sitepu, Sempa. 1993. Sejarah- Pijer Podi Adat Ngeluh Suku Karo Indonesia. Medan, Indonesia: Bali “Scan \& Percetakan”.

Snijders,Adelbert. 2004. Antopologi Filsafat: Manusia Paradoks dan Seruan. Yogyakarta, Indonesia: Penerbit Kanisius.

Suka, S.K. Ginting. 2001. Ranan Adat; Orat ngeluh- Rikut Kiniteken Kalak KAro Ope Tubuh she Idilo Dibata. Medan, Indonesia: Merga Silima.

Wardhani, D. 2008. Media Relations Sarana Membangun Reputasi Organisasi. Yogyakarta, Indonesia: Graha Ilmu.

West, R., and Turner, L., H. (2009). Introducing communication theory; analysis and application. (3rd ed.) Avenue of the American. NY. Dialih bahasakan oleh Maria Natalia Damayanti Maer. Dengan judul Pengantar Teori komunikasi: analisis dan applikasi. (1st ed.) Jakarta, Indonesia: Salemba Humanika.

Jurnal

Andung, Petrus Ana. 2010. “Perspektif Komunikasi Ritual mengenai pemanfaatan Natoni sebagai media komunikasi tradisional dalam masyarakat adat boti dalam di kabupaten Timur Tengah Selatan, Propinsi Nusa Tenggara Timur" Jurnal Ilmu Komunikasi, Vol. 8, Januari- April, hal 3-6.UPNYK.

\section{Skripsi}

Eka Priyanti, (2012) Ertutur Dikalangan Generasi Muda Etnis Karo Di Kelurahan Tanah Merah Kecamatan Binjai Selatan Kota Binjai. UNIMED Library. Sumatera Utara. http://digilib. unimed.ac.id/ertutur-di-kalangangenerasi-muda-etnis-karo-dikelurahan-tanah-merah-kecamatanbinjai-selatan-kota-binjai-24309. html

Tarigan, Krista Juniati. 2007. Studi Deskriptif mengenai Value Schwartz pada Masyarakat Desa " $X$ " dengan Latar Belakang Budaya Karo di Kabupaten Karo. Sarjana Psikologi. Universitas Kristen Maranatha Bandung.

Hutagaol, Ronald. 2013. Penerapan Tradisi Batak Toba Di Yogyakarta; Studi Deskriptif Penerapan Martarombo dalam Komunikasi Anak Muda Perantau Suku Batak Toba di Yogyakarta. Sarjana Komunikasi. Universitas Gajah Mada. 